\title{
Hibiscus sabdariffa extract augments the renoprotective effect of lisinopril against streptozotocin-induced diabetic nephropathy in rats
}

\author{
Nehal S. Wahba ${ }^{1}$, Amr A. A. Mahmoud ${ }^{1 *}$, Mona F. Mahmoud ${ }^{1}$, Mohammed N. M. \\ Zakaria $^{1 \S}$ \\ ${ }^{1}$ Department of Pharmacology, Faculty of Pharmacy, Zagazig University, Zagazig 44519, Egypt \\ * Corresponding Author E-mail: aamahmoud@ pharmacy.zu.edu.eg \\ ${ }^{\S}$ This paper is dedicated to the memory of Prof. Dr. Mohammed Zakaria, who recently passed \\ away.
}

\begin{abstract}
Diabetic nephropathy (DN) is the main cause of end stage renal disease. Complex mechanisms are implicated in the pathogenesis of DN including the accumulation of advanced glycation end products (AGEs), oxidative stress, and inflammation mediated through the upregulation of toll-like receptor 4 (TLR4). Hibiscus sabdariffa is widely used in food products possessing anti-oxidative, anti-inflammatory, anti-diabetic, and anti-hypertensive effects. The present study aimed to investigate the role of hibiscus extract against streptozotocin(STZ)induced DN compared to lisinopril, and to evaluate the effects of their combined administration. Rats were treated with hibiscus extract $(100,200$, or $400 \mathrm{mg} / \mathrm{kg})$, lisinopril $(5 \mathrm{mg} / \mathrm{kg})$, or lisinopril plus hibiscus extract $(2.5 / 100 \mathrm{mg} / \mathrm{kg})$ for 8 weeks. Hibiscus extract caused a dosedependent improvement of nephropathy, and suppressed oxidative stress, inflammation, and the upregulation of TLR4 induced by STZ. The effects of hibiscus extract $(400 \mathrm{mg} / \mathrm{kg})$ were comparable to lisinopril $(5 \mathrm{mg} / \mathrm{kg})$. Interestingly, the combined administration of lisinopril plus hibiscus extract $(2.5 / 100 \mathrm{mg} / \mathrm{kg})$ significantly improved the manifestations of nephropathy better than lisinopril or hibiscus extract alone. These results might support the application of hibiscus extract as an alternative to the conventional angiotensin-converting enzyme inhibitors (ACEIs) or at least as an adjunctive to augment their effects in DN.
\end{abstract}

Key words: $\quad$ Diabetic nephropathy; Hibiscus sabdariffa; Toll-like receptor 4; Oxidative stress; Inflammation

\section{INTRODUCTION}

Diabetic nephropathy $(\mathrm{DN})$ is a serious microvascular complication of diabetes mellitus afflicting approximately one third of diabetic patients. It is considered the main cause of end stage renal diseases (Packham et al., 2012). The characteristic manifestation of DN includes microalbuminuria, which is followed by deterioration of the renal function. This is accompanied by thickening and loss of the charge barrier of the glomerular basement membrane (Parving, 2001) and increased amount of mesangial matrix, which eventually can lead to glomerulosclerosis and tubulo-interstitial fibrosis (Kanwar et al., 2008). The mechanisms implicated in the pathogenesis of DN are complex Sustained hyperglycemia has been suggested as the main player that enhances the generation of advanced glycation end products (AGEs), the production of reactive oxygen species (ROS), and the release of inflammatory cytokines (Sun et al., 2013). Tubulointerstitial inflammation is suggested to be mediated through the upregulation of TLR4 via a high glucose-dependent effect (Lin et al., 2012). Management strategies to delay the progression of $\mathrm{DN}$ focus on tight glycemic control and inhibition of the 
rennin-angiotensin system (RAS), which can be accomplished by using either ACEIs or Hibiscus sabdariffa has been used traditionally to prepare hot and cold beverages, as a flavoring agent, and as a herbal medicine. Hibiscus possesses a variety of pharmacological effects including antioxidative, anti-inflammatory (Fakeye, 2008), anti-diabetic, anti-hypertensive (HerreraArellano et al., 2004; Onyenekwe et al., 1999), anti-hyperlipidemic, and anti-tumor effects.

The present study was conducted to investigate the role of hibiscus calyces aqueous extract against DN. We tried also to shed some light on the possible underlying mechanisms of hibiscus extract accentuating its effect on TLR4 pathway as a new target for hibiscus in DN. In addition, we were interested in comparing the effects of hibiscus to lisinopril, an ACEI, which is used clinically in the management of DN. Another interesting target was to compare the effect a combination of lisinopril and hibiscus extract to either treatment alone in order to evaluate the potential capacity of hibiscus to augment the protective effects of lisinopril in DN.

\section{MATERIALS AND METHODS}

\section{Experimental animals}

Adult male Wistar rats (180-205 g) were used in the present study. Animals were purchased from the Egyptian Organization for Biological Products and Vaccines (Cairo, Egypt). Rats were acclimatized for one week prior to experiments. The animals were kept at controlled temperature $\left(23 \pm 2^{\circ} \mathrm{C}\right)$, humidity $(60 \pm 10 \%)$ and light/dark cycle $(12 / 12$ h). Rats were supplied with commercially available normal chow diet (El Nasr Company for Pharmaceutical Chemicals, Zagazig, Egypt) and allowed free access to water. angiotensin II receptor blockers (ARBs) $(\mathrm{Ng}$ et al., 2005).

\section{Ethical statement}

All applicable international, national, and/or institutional guidelines for the care and use of animals were followed. All procedures performed in studies involving animals were approved by the local authorities, Ethical Committee for Animal Handling at Zagazig University (ECAHZU), at the Faculty of Pharmacy, Zagazig University, Egypt in accordance with the recommendations of the Weatherall report. Every effort was done to minimize the number of animals used and their suffering during experiments.

\section{Drugs and chemicals}

Streptozotocin (STZ, CAS Number: 18883-66-4) and lisinopril (CAS Number: 83915-83-7) were purchased from SigmaAldrich (St. Louis, MO, USA). STZ was dissolved in a freshly prepared ice-cold sodium citrate buffer $(10 \mathrm{mmol} / \mathrm{L}, \mathrm{pH} 4.5)$, while lisinopril was dissolved in distilled water immediately before administration.

\section{Hibiscus sabdariffa extract Plant material}

Dry dark-red calyces of Hibiscus sabdariffa (Family Malvaceae) were obtained from Faculty of Agriculture, Zagazig University, Egypt and identified by Dr. Mohammed Abd El-Kader, Department of Horticulture-Decoration Plants, Faculty of Agriculture, Zagazig University, Egypt. A voucher specimen has been kept for future reference at the Department of Pharmacology, Faculty of Pharmacy, Zagazig University, Egypt.

\section{Preparation of the aqueous extract}

The collected calyces were powdered, $150 \mathrm{~g}$ of dried powder was macerated with hot distilled water $\left(95^{\circ} \mathrm{C}, 6 \mathrm{~L}\right)$ for $2 \mathrm{~h}$, the solution was then filtered and lyophilized to 
obtain $75 \mathrm{~g}$ of hibiscus extract, which was stored at $4^{\circ} \mathrm{C}$ (Wang et al., 2011). Aqueous solutions of hibiscus extract were prepared at a concentration of $80 \mathrm{mg} / \mathrm{ml}$ just before administration.

\section{Characterization of the extract}

Quantitative analysis of the content of phenolic compounds, flavonoids and anthocyanins contained in hibiscus calyces extract was performed according to the methods described by Siriwoharn et al. (2004), Zhishen et al. (1999), and Česonienè et al. (2012), respectively. In addition, highperformance liquid chromatography (HPLC) analysis for the extract was performed using 1260 LC System (Agilent Technologies, Santa Clara, CA, USA) equipped with Zorbax Eclipse XDB C18 column (4.5 mm x $150 \mathrm{~mm}, 5 \mu \mathrm{m})$. HPLC system was coupled to 6410 QQQ mass spectrometer (MS) (Agilent Technologies, Santa Clara, CA, USA) operating in both negative and positive modes. Briefly, the extract was filtered and $10 \mu \mathrm{L}$ were injected onto the column. Two gradient programs were used for the analysis. The mobile phase in gradient program 1 contained two solvents (A, water/acetonitrile = 90:10 (1\% formic acid) and B; acetonitrile) run by a linear gradient method at $35^{\circ} \mathrm{C}$ as follows: 0 min, 5\% (B); 20 min 20\% (B); 25 $\min 40 \%(\mathrm{~B}) ; 30 \mathrm{~min} 5 \%(\mathrm{~B}) ; 35 \mathrm{~min}$, isocratic of B $5 \%$ (flow rate $=0.5 \mathrm{ml} / \mathrm{min}$ ). The mobile phase in gradient program 2 contained two solvents (A, water (10\% formic acid); B, acetonitrile) run by a linear gradient method at $35^{\circ} \mathrm{C}$ as follows: $0 \mathrm{~min}$, 0\% (B); 13 min 20\% (B); 20 min 30\% (B); 25 min $80 \%(\mathrm{~B}) ; 30$ min 0\% (B); 35 min, isocratic of B $0 \%$ (Rodriguez-Medina et al., 2009).

\section{Induction of diabetes and DN}

Following an overnight fasting, type 2 diabetes was induced by a single injection of STZ (55 mg/kg, i.p.). After $72 \mathrm{~h}$, fasting tailvein glucose level was measured using a glucometer (GM100, Bionime GmbH, Berneck, Switzerland) and only those animals having blood glucose level > 250 $\mathrm{mg} / \mathrm{dL}$ were considered diabetic and used in the study (Kumar et al., 2010; Wang et al., 2011). DN was evident in diabetic rats after 8 weeks.

\section{Experimental design}

Rats were randomly divided into seven groups (6 rats each). Group I (Control): normal rats received the vehicle only. Group II (STZ): diabetic rats received the vehicle only. Groups III, IV and V (H100, H200 and H400): diabetic rats received 100, 200, or $400 \mathrm{mg} / \mathrm{kg}$ of hibiscus extract daily. Group VI (L5): diabetic rats received lisinopril (5 $\mathrm{mg} / \mathrm{kg}$ ) daily. Group VII (L2.5+H100): diabetic rats received a combination of lisinopril (2.5 $\mathrm{mg} / \mathrm{kg} /$ day $)$ plus hibiscus extract (100 mg/kg/day), where lisinopril was administered $2 \mathrm{~h}$ following hibiscus extract administration. All treatments were administrated by oral gavage between 11:00 am and 1:00 pm. The administration of hibiscus extract and lisinopril continued throughout the experimental period daily for 8 consecutive weeks. Based on the previous data in the literature, the doses of hibiscus extract (Wang et al., 2011; Yang et al., 2013), and lisinopril (Kabour et al., 1995; Kuno et al., 2003) were selected.

\section{Methods}

\section{Urine, blood and tissue sampling}

Rats were fasted overnight, spot urine samples were collected for the measurement of urinary albumin, urinary creatinine and albumin/creatinine ratio. Blood samples were collected from the retro-orbital sinus of rats using heparinized microcapillary tubes. The blood samples were allowed to clot for 30 min at room temperature. Serum was separated by centrifugation at $3000 \mathrm{rpm}$ for $15 \mathrm{~min}$ and stored at $-20{ }^{\circ} \mathrm{C}$ for further biochemical measurements. Rats were 
euthanized by cervical dislocation and right kidneys were removed, thoroughly rinsed with saline, and then divided into two parts. The first part was immediately snap frozen in liquid nitrogen and stored at $-80^{\circ} \mathrm{C}$ for further biochemical measurements, while the other part was fixed in $10 \%$ neutral buffered formalin at room temperature for histopathological examination.

\section{Measurement of blood glucose and serum insulin level}

Blood glucose level was measured using an electrochemical glucometer (GM100, Bionime GmbH, Berneck, Switzerland). Serum insulin level was measured by sandwich enzyme-linked immunosorbent assay (ELISA) using a diagnostic kit supplied by Millipore (Billerica, MA, USA).

\section{Kidney function tests}

Serum creatinine and urea levels, as well as urine creatinine level were measured by colorimetric methods using diagnostic kits provided by Diamond Diagnostics (Cairo, Egypt). Urine albumin level was measured by a highly sensitive two-site ELISA assay using a kit provided by Kamiya Biomedical Company (Seattle, WA, USA). Further, urine albumin/creatinine ratio (UACR) was calculated according to the following formula: UACR $(\mathrm{mg} / \mathrm{g})=$ urine albumin $(\mathrm{mg} / \mathrm{dL}) /$ urine creatinine $(\mathrm{g} / \mathrm{dL})$

\section{Measurement of AGEs}

Serum AGEs concentration was measured by ELISA technique using a rat kit supplied by MyBioSource (San Diego, CA, USA).

\section{Determination of oxidative stress markers in kidney tissue}

The levels of malondialdehyde (MDA), reduced glutathione (GSH), nitric oxide (NO), and the activities of catalase (CAT) and superoxide dismutase (SOD) in the tissue homogenates of kidney were measured using kits provided by Biodiagnostic (Giza, Egypt).

Quantitative real-time PCR for the expression of inducible nitric oxide synthase (iNOS), TLR4, and nuclear factor-kappa $B(\mathrm{NF}-\kappa \mathrm{B})$ in kidney tissue

Total RNA was extracted from kidney tissue using Trizol reagent (Invitrogen, Carlsbad, CA, USA). The RNA pellet was resuspended in DEPC-treated water. The quality and concentration of the RNA were assessed using the OD 260/280 ratio, and only samples with ratios above 1.5 were used. Total RNA was reverse transcribed using RevertAid Premium Reverse Transcriptase-Kit (Fermentas International Inc., Burlington, Canada). Briefly, RevertAid $\mathrm{H}$ Minus M-MuLV Reverse Transcriptase was added to dNTP Mix (10 mM), $5 \mathrm{x}$ reaction buffers and random hexamer primers; the mixture was subjected to cDNA synthesis cycling conditions at $37{ }^{\circ} \mathrm{C}$ for 30 min and at $85^{\circ} \mathrm{C}$ for $5 \mathrm{~min}$.

Real-time quantitative polymerase chain reaction (qPCR) was performed using $\mathrm{ABI}$ PRISM 7500 sequence detector system (Applied Biosystems, Foster City, CA, USA), using the Maxima SYBR Green qPCR Kit (Fermentas International Inc., Burlington, Canada). The primer sequences used for iNOS, TLR4, and NF- $\kappa \mathrm{B}$ are listed in Table 1. Reaction mixtures contained $10 \mathrm{pmol} / \mu \mathrm{l}$ of each primer, $12.5 \mu \mathrm{l}$ Maxima SYBR mix and $5.5 \mu \mathrm{l}$ nuclease free water. An amount of $5 \mu \mathrm{l}$ of cDNA was added to each reaction mix. The thermal cycling protocol consisted of 2 min at $50{ }^{\circ} \mathrm{C}$ and $10 \mathrm{~min}$ at $95^{\circ} \mathrm{C}$, followed by 40 cycles of $95^{\circ} \mathrm{C}$ for $30 \mathrm{~s}$ and $60{ }^{\circ} \mathrm{C}$ for $30 \mathrm{~s}$ and $72{ }^{\circ} \mathrm{C}$ for $30 \mathrm{~s}$. Data were calculated using Sequence Detection Software from PE Bio systems v. 1.7 (Foster City, CA, USA). Relative expression of studied genes was calculated using the comparative $\mathrm{C}_{\mathrm{t}}$ method. All values were normalized to $\beta$-actin gene expression and reported as fold change from control group 
Table 1: Gene-specific primer sequences used for real-time polymerase chain reaction

\begin{tabular}{|c|c|c|}
\hline Gene & Forward primer & Reverse Primer \\
\hline iNOS $^{a}$ & 5'-GGGCCACCTTTATGTTTGTG-3' & 5'-CCTCAACCTGCTCCTCACTC-3' \\
\hline TLR4 $^{b}$ & 5'-GCCGGAAAGTTATTGTGGTGGT-3' & 5'-ATGGGTTTTAGGCGCAGAGTTT-3' \\
\hline $\mathbf{N F - k B ^ { c }}$ & 5'-GCTTACGGTGGGATTGCATT-3' & 5'-TTATGGTGCCATGGGTGATG-3' \\
\hline$\beta$-Actin & 5'-TGTTTGAGACCTTCAACACC-3' & 5'-TAGGAGCCAGGGCAGTAATC-3' \\
\hline
\end{tabular}

Determination of tumor necrosis factoralpha (TNF- $\alpha)$ and transforming growth factor-beta 1 (TGF- $\beta 1$ ) in kidney tissue

TNF- $\alpha$ and TGF- $\beta 1$ levels in kidney tissue homogenates were measured by ELISA assay using kits supplied by $R \& D$ systems (Minneapolis, MN, USA).

\section{Histopathological examination}

Kidney specimens were fixed using $10 \%$ neutral buffered formalin. After proper fixation, the specimens were dehydrated in ethyl alcohol of increasing concentrations (70\%, 90\%, 100\%), cleared in xylol, impregnated and then embedded in paraffin wax. Sections, $5 \mu \mathrm{m}$ thick, were cut using a rotatory microtome. The sections were then stained with H\&E and Mallory's trichrome stains and examined under light microscope. $H \& E$ stain is used routinely for studying the general histological structure giving the cytoplasm red color and the nucleus blue color (Kiernan, 1999). On the other hand, Mallory's trichrome stain is used to visualize collagen fibers (Drury and Wallington, 1980).

\section{Statistical Analysis}

All data are expressed as mean \pm standard error of the mean (SEM). Statistical analysis was performed using Graphpad prism software v.6 (GraphPad Software Inc., La Jolla, CA, USA). The statistical significance of differences between groups was tested using one-way analysis of variance (ANOVA) followed by Tukey's Post-test. A significant difference was assumed for values of $P<0.05$.

\section{RESULTS}

Characterization of hibiscus calyces extract

Table 2 shows the components of hibiscus extract. The contents of polyphenols, flavonoids, and anthocyanins were $6.5 \mathrm{mg} / \mathrm{g}, 4.79 \mathrm{mg} / \mathrm{g}$, and $6.1 \mathrm{mg} / \mathrm{kg}$, respectively. Further, the compounds identified in hibiscus extract by HPLC/MS analysis are listed in Table 3.

Table 2: Functional composition of Hibiscus sabdariffa calyces aqueous extract

\begin{tabular}{lc}
\hline Component & Content $(\mathbf{m g} / \mathbf{g})$ \\
\hline Polyphenols & 6.5 \\
Flavonoids & 4.79 \\
Anthocyanins & 6.1 \\
\hline
\end{tabular}


Table 3: Mass spectral negative mode (gradient program 1) and positive mode (gradient program 2) in the Hibiscus sabdariffa aqueous extract

\begin{tabular}{ccccccc}
\hline \multirow{2}{*}{ RT } & $\begin{array}{c}\text { Molecular } \\
\text { formula }\end{array}$ & $\begin{array}{c}\text { M/Z } \\
\text { Exp. }\end{array}$ & $\begin{array}{c}\text { M/Z } \\
\text { Calc. }\end{array}$ & $\begin{array}{c}\text { MS/MS } \\
\text { Fr. }\end{array}$ & Proposed compound \\
\hline 1 & 2.15 & $\mathrm{C}_{21} \mathrm{H}_{19} \mathrm{O}_{12}$ & 463 & 463.0882 & 301.1 & Quercetin 3-glucoside \\
\hline 2 & 2.3 & $\mathrm{C}_{6} \mathrm{H}_{7} \mathrm{O}_{8}$ & 207 & 207.0146 & 189.127 & Hydroxycitric acid \\
\hline 3 & 2.5 & $\mathrm{C}_{6} \mathrm{H}_{5} \mathrm{O}_{7}$ & 189 & 189.0041 & 127 & Hibiscus acid \\
\hline 4 & 3.5 & $\mathrm{C}_{16} \mathrm{H}_{17} \mathrm{O}_{9}$ & 353.1 & 353.0878 & 191.1 & Chlorogenic acid \\
\hline 5 & 4.5 & $\mathrm{C}_{16} \mathrm{H}_{17} \mathrm{O}_{9}$ & 353.1 & 353.0878 & 191,179, & Chlorogenic acid isomer I \\
\hline 6 & 5.05 & $\mathrm{C}_{27} \mathrm{H}_{29} \mathrm{O}_{15}$ & 593.1 & 593.1512 & 285.1 & Kaempferol 3-O-rutinoside \\
\hline 7 & 6.5 & $\mathrm{C}_{27} \mathrm{H}_{29} \mathrm{O}_{16}$ & 609.3 & 609.1461 & 301.1 & Quercetin 3-rutinoside \\
\hline 8 & 9.55 & $\mathrm{C}_{16} \mathrm{H}_{15} \mathrm{O}_{8}$ & 335 & 335.0772 & 160.9 & 5-O-Caffeoylshikimic acid \\
\hline 9 & 11.06 & $\mathrm{C}_{30} \mathrm{H}_{25} \mathrm{O}_{13}$ & 593 & 593.1301 & 447.1, & Kaempferol 3-(p- \\
\hline 10 & 12.06 & $\mathrm{C}_{16} \mathrm{H}_{17} \mathrm{O}_{9}$ & 353.1 & 353.0878 & $191.1,179$ & Chlorogenic acid isomer II \\
\hline 11 & 23.5 & $\mathrm{C}_{26} \mathrm{H}_{27} \mathrm{O}_{16}$ & 595 & 595.1305 & 463 & Quercetin 3-sambubioside \\
\hline 12 & 23.5 & $\mathrm{C}_{26} \mathrm{H}_{27} \mathrm{O}_{16}$ & 595.1 & 595 & - & Delphinidin 3-sambubioside \\
\hline 13 & 27.45 & $\mathrm{C}_{26} \mathrm{H}_{27} \mathrm{O}_{15}$ & 579 & 579 & 317.2 & Cyanidin 3-sambubioside \\
\hline 14 & 28.05 & $\mathrm{C}_{18} \mathrm{H}_{19} \mathrm{NO}_{4}$ & 311.1 & 312.1241 & 136 & N-Feruloyltyramine \\
\hline 15 & 30.2 & $\mathrm{C}_{15} \mathrm{H}_{9} \mathrm{O}_{7}$ & 301.1 & 301.0354 & - & Quercetin \\
\hline \multicolumn{7}{c}{ Positive Mode } \\
\hline 1 & 6.5 & $\mathrm{C}_{9} \mathrm{H}_{7} \mathrm{O}_{3}$ & 163.2 & 163.038 & - & 7-Hydroxycoumarin \\
\hline 2 & 8.55 & $\mathrm{C}_{26} \mathrm{H}_{29} \mathrm{O}_{16}$ & 597.2 & 597.14 & 304.3 & Delphinidin 3-sambubioside \\
\hline 3 & 13.05 & $\mathrm{C}_{26} \mathrm{H}_{29} \mathrm{O}_{15}$ & 581.2 & 581.149 & 261.1 & Cyanidin 3-sambubinoside \\
\hline 4 & 2.35 & $\mathrm{C}_{6} \mathrm{H}_{7} \mathrm{O}_{7}$ & 191.1 & 191.0181 & - & Dihydrogen citrate \\
\hline
\end{tabular}

Exp., experimental; Calc., calculated; Fr., fraction.

\section{Effect on body weight (BW) and glycemic parametes}

At the beginning of the study, the mean body weights of all groups were similar (Fig. 1a). After 8 weeks, diabetic rats had significantly lower BW (131 \pm 4 vs. $243 \pm 6.3$ $\mathrm{g}, P<0.05)$ compared to the control group. Treatment of diabetic rats with hibiscus extract at doses of 100,200 or 400 $\mathrm{mg} / \mathrm{kg} /$ day caused significant, dosedependent increase of BW by $22.4 \%, 35.6 \%$ and $48.9 \%$, respectively, compared to diabetic rats that received STZ alone. Similarly, L5 significantly resulted in a significant increase in BW by $62.7 \%$ ( $P<$ $0.05)$ compared to STZ diabetic group. The administration of L2.5+H100 significantly increased BW by $75.48 \%(P<0.05)$ compared to STZ diabetic rats. Further, the increase in BW caused by $\mathrm{L} 2.5 / \mathrm{H} 100$ was significantly higher compared to H400 or L5 alone (Fig. 1b).

Moreover, diabetic rats had significantly elevated blood glucose level (534 \pm 19.6 vs. $99 \pm 3.5 \mathrm{mg} / \mathrm{dL}, P<0.05)$ and significantly reduced serum insulin level $(0.25 \pm 0.01$ vs. $4.2 \pm 0.12 \mu \mathrm{g} / \mathrm{L}, P<0.05)$ compared to the control group. Treatment of diabetic rats with hibiscus extract at doses of 100, 200 or $400 \mathrm{mg} / \mathrm{kg} /$ day provoked significant, dosedependent reduction of blood glucose level by $16 \%, 40 \%$ or $57 \%$, respectively $(P<$ $0.05)$, as well as significant $(P<0.05)$, dosedependent elevation in serum insulin level 
by $283 \%, 635 \%$ or $838 \%$, respectively, compared to diabetic rats. Likewise, L5 caused a significant reduction in blood glucose level by $60 \%$ and a significant increase in serum insulin level by $992 \%$ compared to the STZ group $(P<0.05)$. There were no significant differences in blood glucose or serum insulin levels between H400 and L5 groups. Furthermore, the combined administration of $\mathrm{L} 2.5+\mathrm{H} 100$ significantly $(P<0.05)$ reduced blood glucose by $79 \%$ and significantly increased serum insulin level by $1530 \%$ compared to STZ diabetic group. Additionally, the improvement induced by the combined administration of $\mathrm{L} 2.5+\mathrm{H} 100$ was significantly higher compared to that of H400 or L5 alone (Fig. 1c, d).
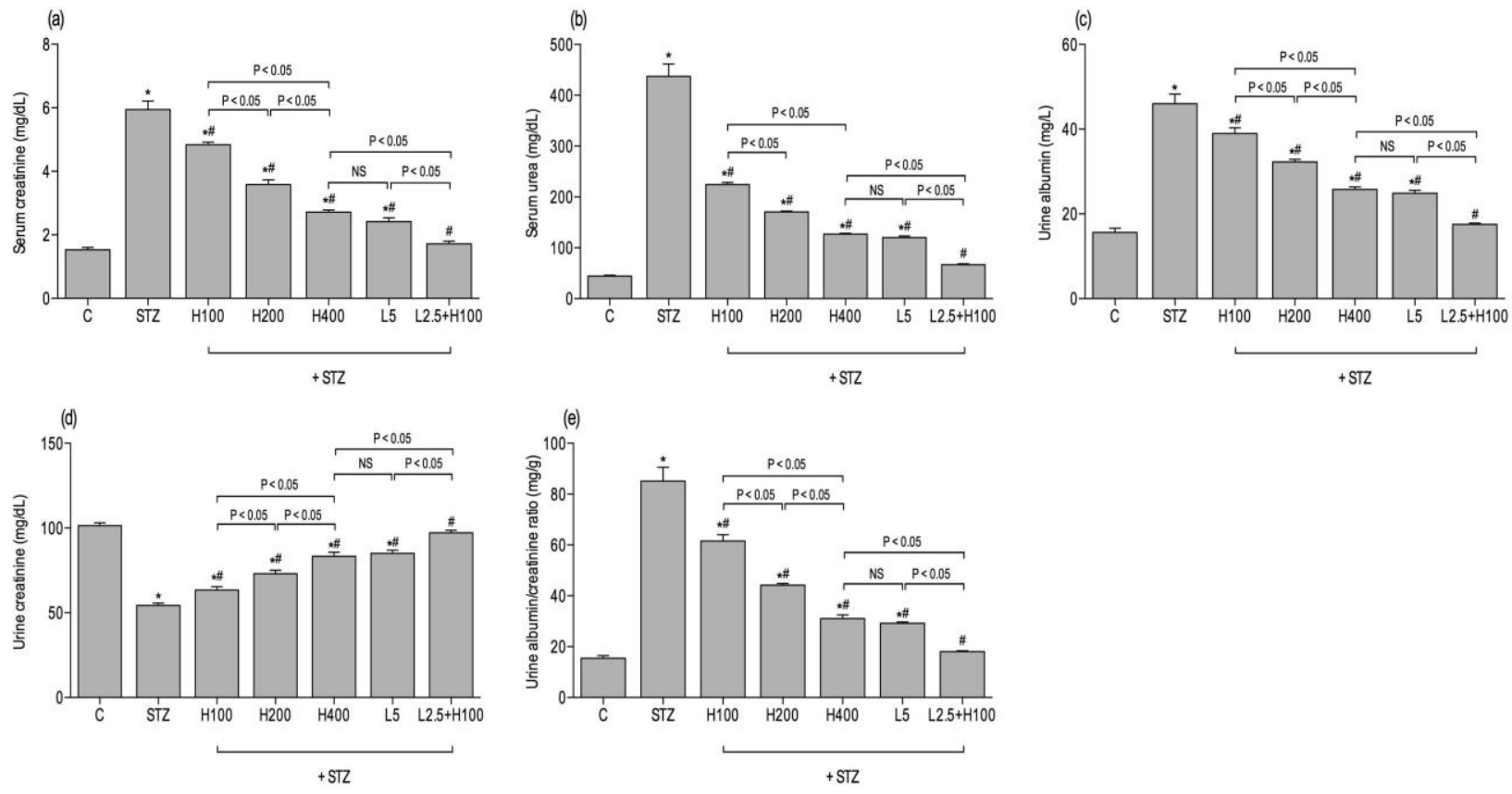

Fig. 1: Effect of hibiscus extract alone or in combination with lisinopril on body weight measured weekly (a), body weight after 8 weeks (b), blood glucose level (c), and serum insulin level (d). Values are expressed as mean \pm SEM $(n=4-6)$. C, control non-diabetic rats; STZ, diabetic rats received a single intraperitoneal injection of streptozotocin $(55 \mathrm{mg} / \mathrm{kg}) ; \mathrm{H} 100, \mathrm{H} 200$, or $\mathrm{H} 400$, diabetic rats received hibiscus extract $(100,200$, or $400 \mathrm{mg} / \mathrm{kg}$, respectively) once daily by oral gavage; L5, diabetic rats received lisinopril $(5 \mathrm{mg} / \mathrm{kg}$ ) once daily by oral gavage; $\mathrm{L} 2.5+\mathrm{H} 100$, diabetic rats received lisinopril (2.5 $\mathrm{mg} / \mathrm{kg}$ ) plus hibiscus extract $(100 \mathrm{mg} / \mathrm{kg}$ ) once daily by oral gavage. Statistical analysis was performed using one-way ANOVA, followed by Tukey's Post-test. *P<0.05 vs. C; $\mathrm{P}<0.05$ vs. STZ; NS, nonsignificant; $\mathrm{P}$ values above the columns indicate significance of difference between the corresponding pairs.

\section{Effect on kidney function tests}

As demonstrated in Fig. 2, STZ induced a significant elevation of serum creatinine $(5.9 \pm 0.28$ vs. $1.5 \pm 0.07 \mathrm{mg} / \mathrm{dL}, P<0.05)$, serum urea $(437 \pm 24$ vs. $45 \pm 1.5 \mathrm{mg} / \mathrm{dL}, P$ $<0.05)$, and urine albumin $(46 \pm 2.3$ vs. 157 $\pm 0.9 \mathrm{mg} / \mathrm{L}, P<0.05)$ levels. It also elevated urine albumin creatinine ratio (UACR) $(85 \pm$
5.5 vs. $15 \pm 1 \mathrm{mg} / \mathrm{g}$ creatinine, $P<0.05$ ); and caused a significant decrease in urine creatinine level $(54 \pm 1.4$ vs. $101 \pm 1.6$ $\mathrm{mg} / \mathrm{dL}, P<0.05)$ compared to the control rats. Treatment of rats with $\mathrm{H} 100, \mathrm{H} 200$, H400, L5, or L2.5+H100 significantly $(P<$ $0.05)$ diminished the alterations induced by STZ on the kidney function parameters. The 
effects exerted by the hibiscus extract were dose-dependent, except for serum urea level, where we observed non-significant changes

between $\mathrm{H} 200$ and $\mathrm{H} 400$. In addition, the effects of H400 and L5 were akin that we did not notice any statistically significant
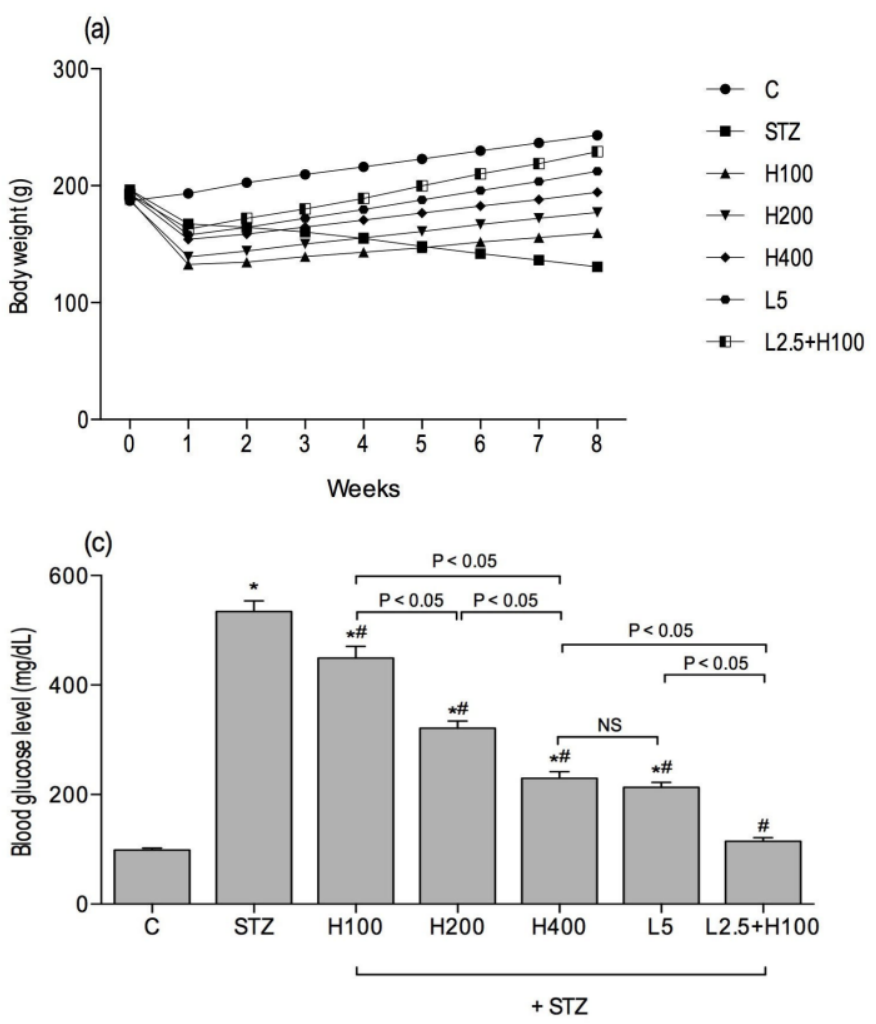

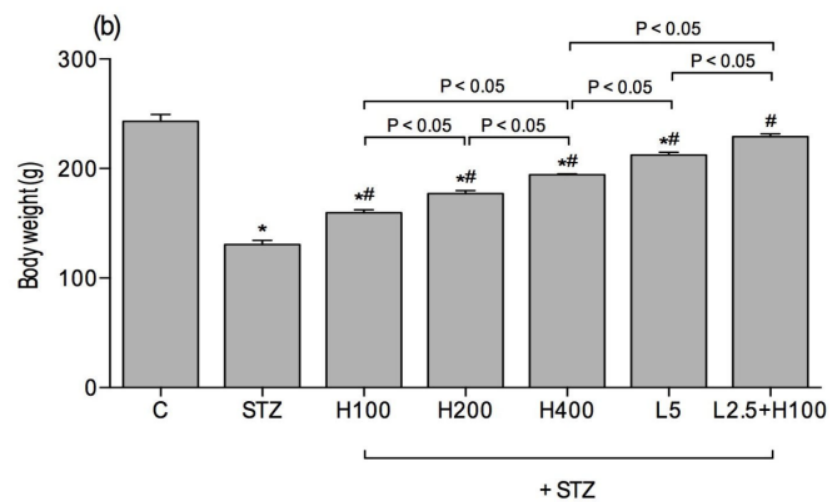

differences between the two groups. Similar to other parameters, the combined administration of $\mathrm{L} 2.5+\mathrm{H} 100$ restored the kidney function close to the normal levels. Furthermore, its effects were significantly better than H400 or L5 alone.

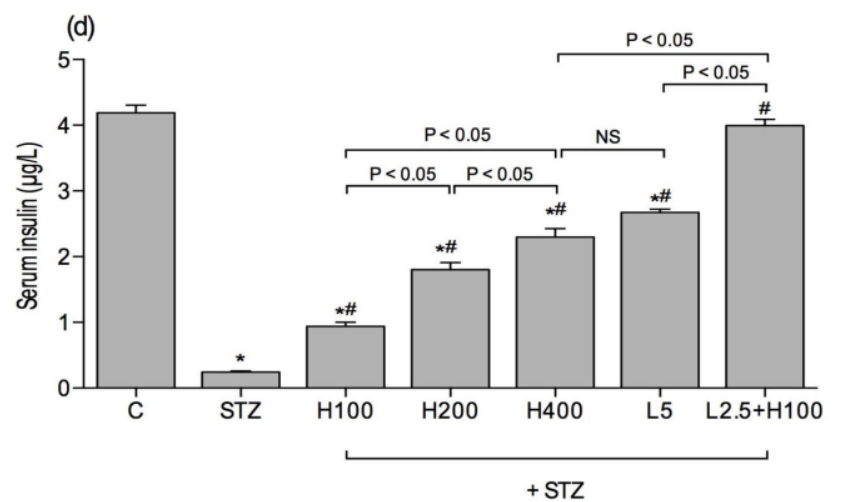

Fig. 2: Effect of hibiscus extract alone or in combination with lisinopril on serum creatinine level (a), serum urea level (b), urine albumin level (c), urine creatinine level (d), and urine albumin/creatinine ratio (e). Values are expressed as mean $\pm \operatorname{SEM}(n=4-6)$. For the definitions of abbreviations, see the caption of Fig. 1. Statistical analysis was performed using one-way ANOVA, followed by Tukey's Post-test. ${ }^{*} \mathrm{P}<0.05$ vs. $\mathrm{C}$; ${ }^{\mathrm{P}}<0.05$ vs. STZ; NS, non-significant; $\mathrm{P}$ values above the columns indicate significance of difference between the corresponding pairs.

\section{Effect on serum AGEs}

STZ diabetic rats had significantly higher serum levels of AGEs ( $49 \pm 2.3$ vs. 9 $\pm 0.6 \mu \mathrm{g} / \mathrm{mL}, P<0.05)$ compared to the control rats. Significant reduction in serum AGEs was provoked by the administration of H100, H200, H400, L5, or the combination of $\mathrm{L} 2.5+\mathrm{H} 100$. Hibiscus extract ameliorated such elevation in a dosedependent fashion, with the highest dose
(400 mg/kg) exhibiting a significant effect compared to the lower dose levels (100 or $200 \mathrm{mg} / \mathrm{kg}$ ). On the other hand, the effect of H400 was comparable to that of L5. The improvement induced by the combined administration of lisinopril plus hibiscus extract was significantly $(P<0.05)$ higher compared to that of H400 or L5 alone (Fig. 3a). 


\section{Effect on oxidative and nitrosative stress markers}

As depicted in Fig. 3b-3e, STZ resulted in significant alterations in oxidative stress markers in the kidney tissue including reduction in GSH level (83\%), CAT activity $(62 \%)$, and SOD activity (87\%); in addition to significant increases in MDA level (140\%) compared to control group. Significant improvements were provoked by the hibiscus extract, L5, and L2.5+H100 combination. The improvement induced by L2.5+H100 seems interesting again because it was significantly higher than H400 or L5 alone. On the other hand, STZ significantly increased nitrosative stress markers including elevation in NO level $(266 \pm 1.9$ vs. $83 \pm 1.3 \mu \mathrm{mol} / \mathrm{L}, P<0.0 .5)$ and the expression of iNOS in kidney tissue (8.5fold, $P<0.05)$ compared to the control group. Hibiscus extract diminished such elevations in a dose-dependent way. The effect of $\mathrm{H} 400$ was comparable to that of L5. Further, the combined administration of $\mathrm{L} 2.5+\mathrm{H} 100$ was successful in restoring the values of these parameters close to their normal levels $(P>0.05)$, and such effect was significantly $(P<0.05)$ higher compared to that of H400 or L5 alone (Fig. 4).
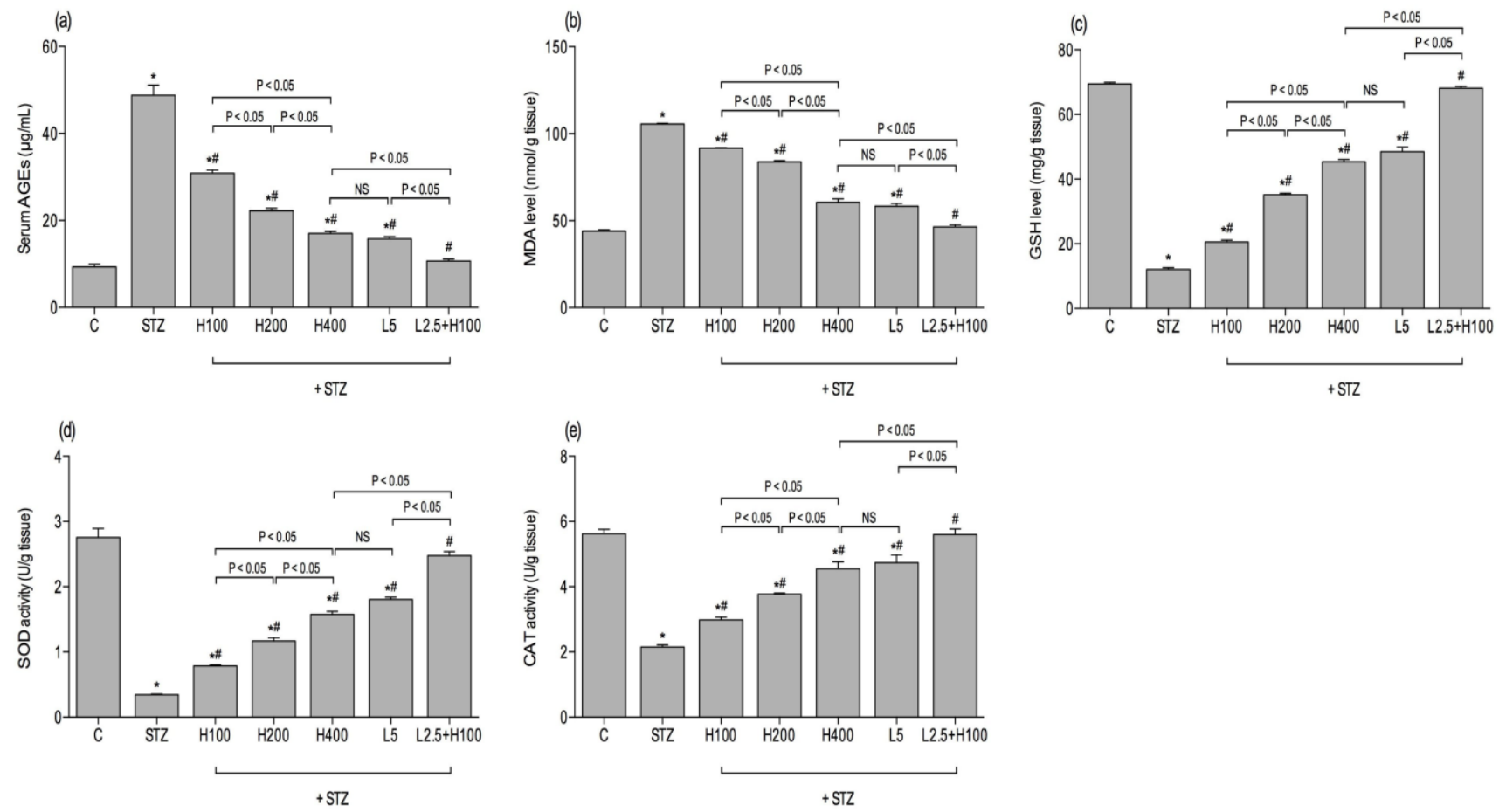

Fig. 3: Effect of hibiscus extract alone or in combination with lisinopril on serum advanced glycation end products (AGEs) level (a), kidney malondialdehyde (MDA) level (b), kidney glutathione (GSH) level (c), kidney superoxide dismutase (SOD) activity (d), and kidney catalase (CAT) activity (e). Values are expressed as mean \pm SEM $(n=4)$. For the definitions of abbreviations, see the caption of Fig. 1. Statistical analysis was performed using one-way ANOVA, followed by Tukey's Post-test. $* \mathrm{P}<0.05$ vs. C; ${ }^{\#} \mathrm{P}<0.05$ vs. STZ; NS, non-significant; $\mathrm{P}$ values above the columns indicate significance of difference between the corresponding pairs. 

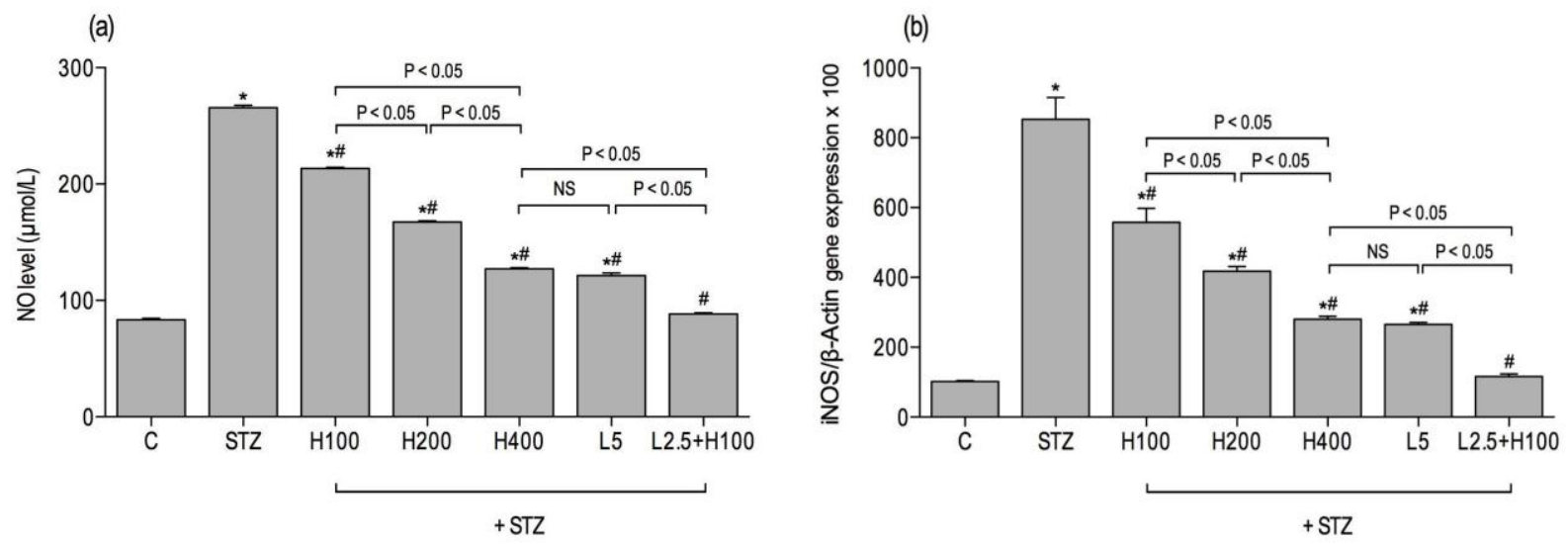

Fig. 4: Effect of hibiscus extract alone or in combination with lisinopril on kidney nitric oxide (NO) level (a) and the expression of inducible nitric oxide synthase (iNOS) in kidney tissue (b). Values are expressed as mean \pm SEM $(n=4)$. For the definitions of abbreviations, see the caption of Fig. 1. Statistical analysis was performed using one-way ANOVA, followed by Tukey's Post-test. $* \mathrm{P}<0.05$ vs. C; ${ }^{\#} \mathrm{P}<0.05$ vs. STZ; NS, non-significant; $\mathrm{P}$ values above the columns indicate significance of difference between the corresponding pairs.

\section{Effect on inflammatory and profibrotic markers}

As depicted in Fig. 5, STZ caused significant upregulation of TLR4 (10.7-fold, $P<0.05)$ and NF-кB (11-fold, $P<0.05)$ expression. It also induced a significant increase in TNF- $\alpha(128 \pm 7.4$ vs. $31 \pm 1.8$ $\mathrm{pg} / \mathrm{mg}$ tissue, $P<0.05)$ and TGF- $\beta 1$ levels $(184 \pm 12.07$ vs. $44 \pm 2.3 \mathrm{pg} / \mathrm{mg}$. tissue, $P<$ 0.05) in kidney tissue compared to the control group. The oral administration of $\mathrm{H} 100$, H200, or H400 significantly downregulated, in a dose-dependent manner, the expression of TLR4 (by $41 \%, 54 \%$, or $69 \%$, respectively, $P<0.05$ ) and $\mathrm{NF}-\kappa \mathrm{B}$ (by $36 \%, 55 \%$, or $70 \%$, respectively, $P<0.05$ ). They also induced a significant reduction of renal TNF- $\alpha$ (by $25 \%, 40 \%$, or $55 \%$, respectively, $P<0.05$ ) and TGF- $\beta 1$ levels (by $22 \%, 42 \%$, or $54 \%$, respectively, $P<$
0.05) compared to STZ diabetic rats. We observed a comparable effect of H400 and L5, as well as a significant improvement induced by the combination L2.5+H100 compared to either group alone.

\section{Histopathological examination}

As shown in Fig. 6a, kidney specimen from control non-diabetic rats showed normal histological structure. Normal rats had also normal distribution of collagen fibers around renal glomeruli and renal tubules (Fig. 7a). On the other hand, kidney specimen from STZ-treated rats showed congested renal corpuscles, some vacuolated and dilated tubules, many degenerated tubules, and marked mononuclear cellular infiltration (Fig. 6b). In addition, many areas of hemorrhage were also observed (Fig. 6c). 
(a)
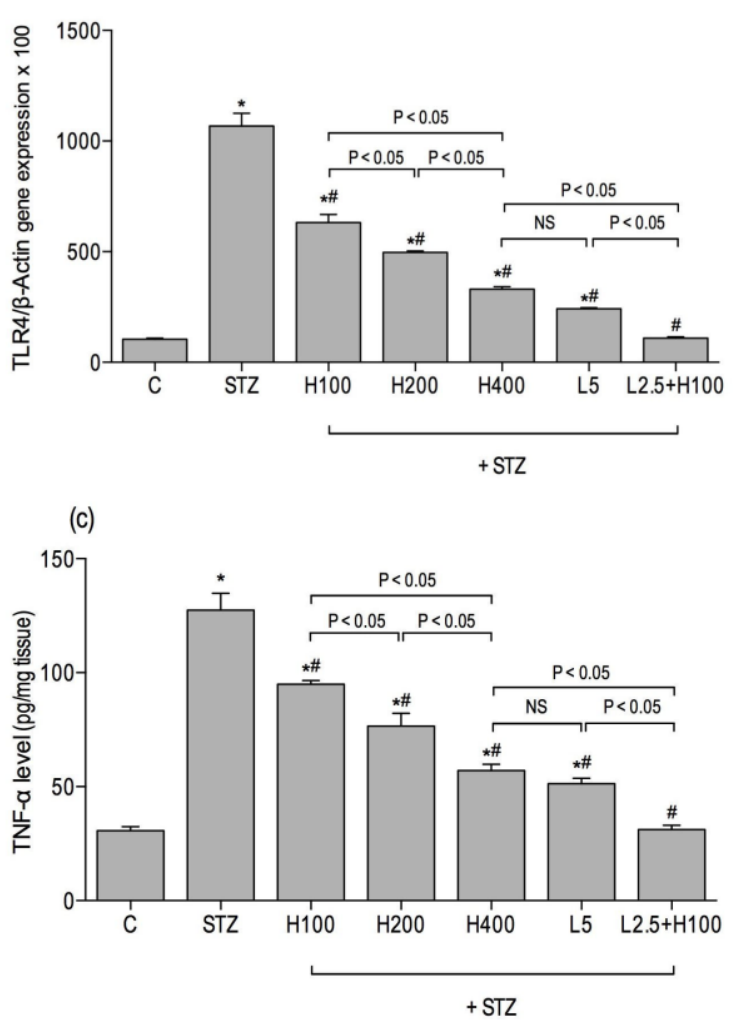

(b)
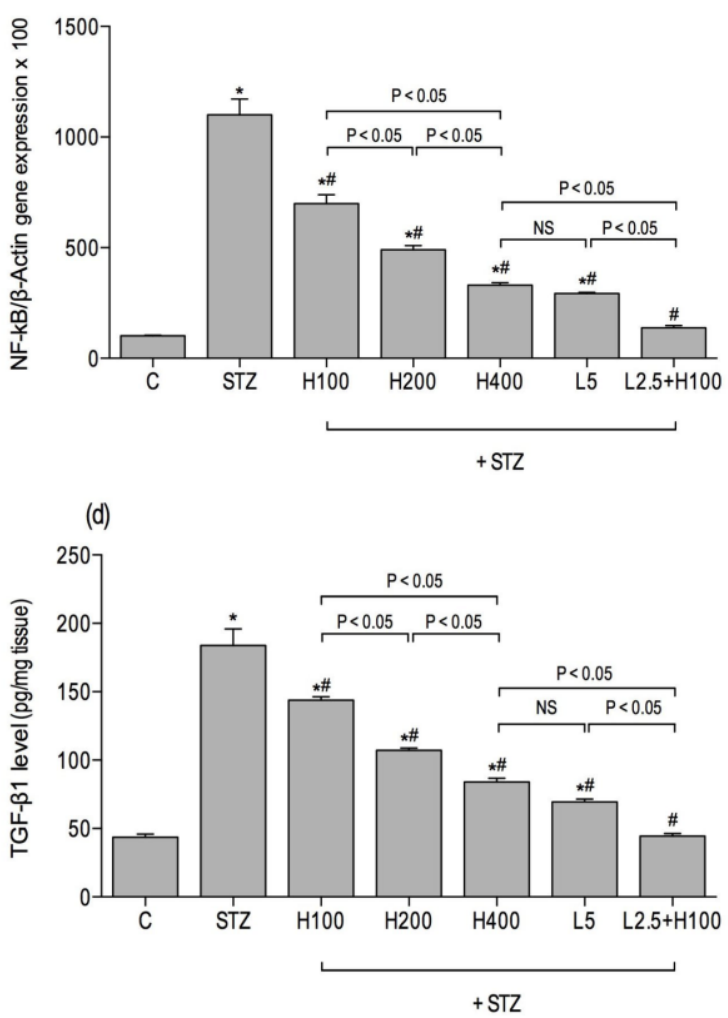

Fig. 5: Effect of hibiscus extract alone or in combination with lisinopril on the expression of toll-like receptor 4 in kidney tissue (a), the expression of nuclear factor-kappa B (NF-kB) in kidney tissue (b), kidney tumor necrosis factor-alpha (TNF- $\alpha$ ) level (c), and kidney transforming growth factor-beta 1 (TGF- $\beta 1)$ level (d). Values are expressed as mean \pm SEM $(n=4)$. For the definitions of abbreviations, see the caption of Fig. 1. Statistical analysis was performed using one-way ANOVA, followed by Tukey's Post-test. ${ }^{*} \mathrm{P}<0.05$ vs. $\mathrm{C}$; ${ }^{\#} \mathrm{P}<0.05$ vs. STZ; NS, non-significant; $\mathrm{P}$ values above the columns indicate significance of difference between the corresponding pairs.

Moreover, diabetic rats showed marked increase in collagen fibers deposition around renal glomeruli and renal tubules (Fig. 7b). Rats treated with H100, H200, or H400 (Fig. $6 \mathrm{~d}$, e, f, respectively) still show some vacuolated and dilated tubules, as well as congested renal corpuscles and marked collagen fibers deposition around renal glomeruli and renal tubules (Fig. 7c, d), particularly seen with the low $(100 \mathrm{mg} / \mathrm{kg})$ and moderate $(200 \mathrm{mg} / \mathrm{kg})$ doses. The administration of the $\mathrm{H} 400$ preserved the normal histologic structure of the renal corpuscles and caused moderate increase in collagen fibers deposition around renal glomeruli and renal tubules (Fig. 7e). Interestingly, marked improvement were observed in kidney specimen from rats treated with L5 or L2.5+H100 with histological picture similar to that of the control group (Fig. 6g, h, respectively). They were associated with little increase in collagen fibers distribution around renal glomeruli and renal tubules (Fig. 7f, g). 


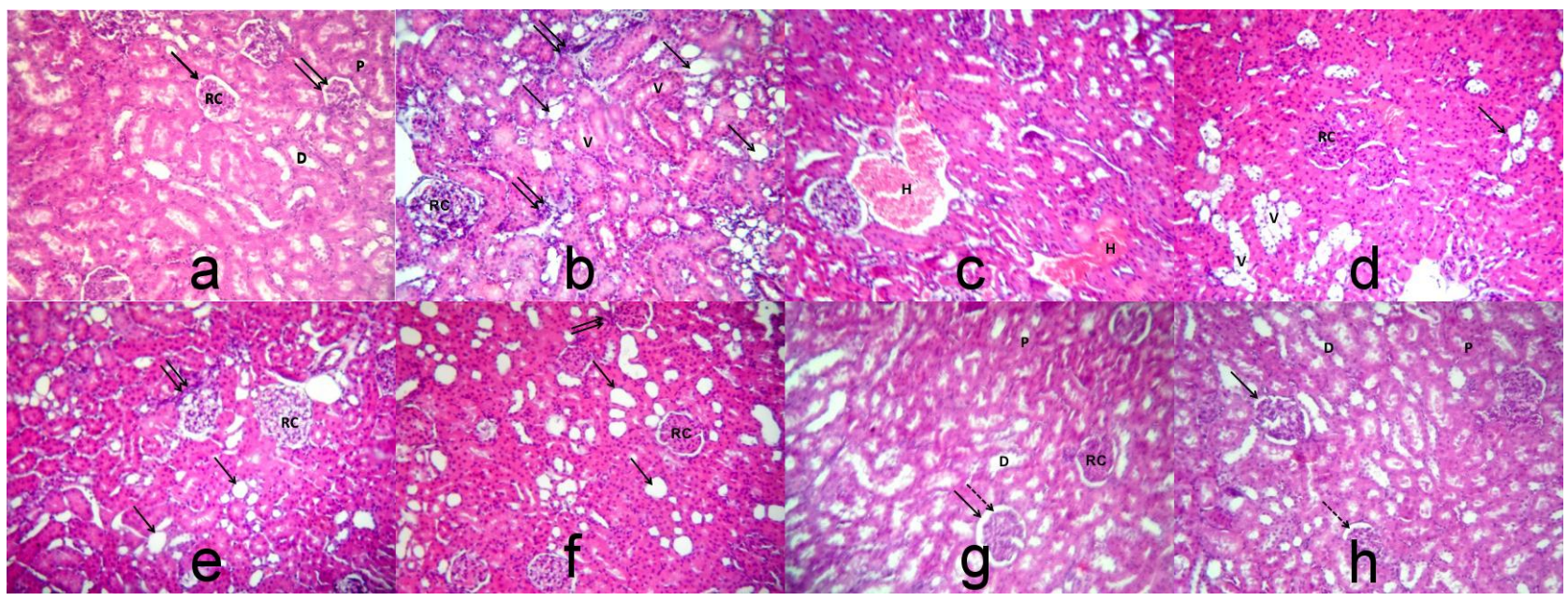

Fig. 6: Effect of hibiscus extract alone or in combination with lisinopril on the histologic picture of kidney tissue specimens stained with H\&E (x 200). Representative light photomicrographs are depicted from (a) control non-diabetic rats showing normal histologic structures with renal corpuscles $(R C)$ surrounded by Bowman's capsules (single arrow), subcapsular space (double arrows), proximal convoluted tubule $(P)$ and distal convoluted tubule $(D)$; (b) STZ diabetic rats showing some dilated tubules (single arrows), vacuolated tubules $(V)$, marked mononuclear cellular infiltration (double arrows) and congested renal corpuscles $(R C)$; (c) STZ diabetic rats showing areas of hemorrhage $(H)$; (d) diabetic rats received low dose of hibiscus extract $(100 \mathrm{mg} / \mathrm{kg}$ ) showing dilated tubules (arrow), many vacuolated tubules $(V)$, and renal corpuscle $(R C)$; (e) diabetic rats received moderate dose of hibiscus extract (200 $\mathrm{mg} / \mathrm{kg}$ ) showing many dilated tubules (arrows), congested renal corpuscle $(R C)$, and mononuclear cellular infiltration (double arrows); (f) diabetic rats received high dose of hibiscus extract ( $400 \mathrm{mg} / \mathrm{kg}$ ) showing many dilated tubules (arrows), normal renal corpuscle $(R C)$, and some mononuclear cellular infiltration (double arrows); (g) diabetic rats received lisinopril $(5 \mathrm{mg} / \mathrm{kg})$ showing marked improvement of the renal tissue with a histological picture similar to that of the control group, renal corpuscle $(R C)$, Bowman's capsule (solid arrow), subcapsular space (dotted arrow), proximal convoluted tubule $(P)$, and distal tubule convoluted $(D) ;($ h) diabetic rats received lisinopril $(2.5 \mathrm{mg} / \mathrm{kg})$ plus hibiscus extract $(100 \mathrm{mg} / \mathrm{kg})$ showing marked improvement of the renal tissue with a histological picture similar to that of the control group, Bowman's capsule (solid arrow), subcapsular space (dotted arrow), proximal convoluted tubule $(P)$, and distal tubule convoluted $(D)$.

\section{DISCUSSION}

The present study provides evidence of the therapeutic effect of hibiscus extract against DN. The results shed light on the underlying mechanisms including the suppression of oxidative and nitrosative stress, as well as the inhibition of inflammatory and profibrotic mediators. We showed also that the actions of hibiscus extract might be mediated in part through the downregulation of TLR4 and its

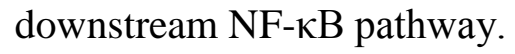




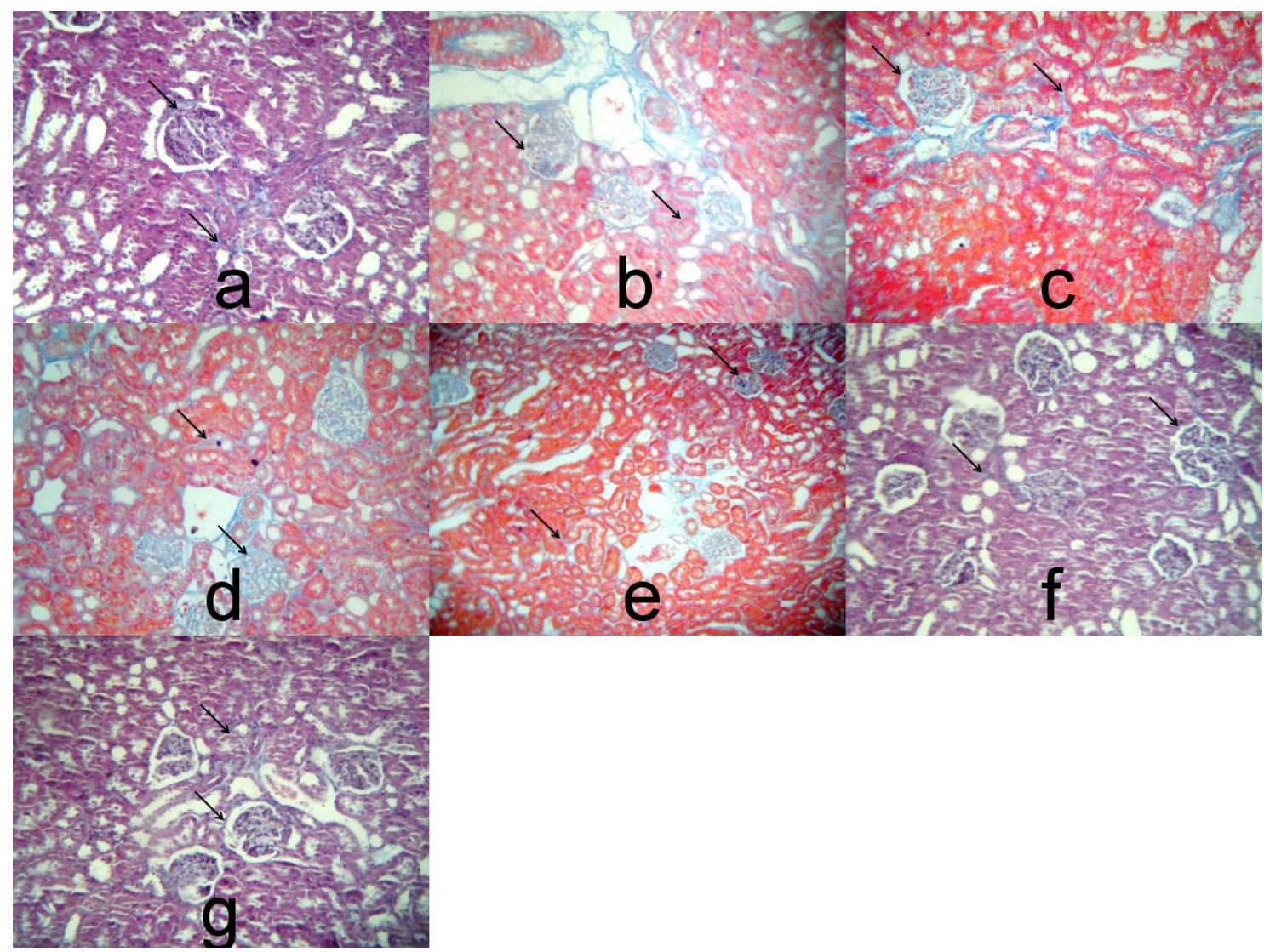

Fig. 7: Effect of hibiscus extract alone or in combination with lisinopril on the collagen deposition in kidney tissue. Specimens were stained with Mallory's trichrome (x 200). Representative photomicrographs are depicted from (a) control non-diabetic rats showing normal distribution of collagen fibers around renal glomeruli and renal tubules (arrows); (b) STZ diabetic rats showing marked increase in collagen fibers deposition around renal glomeruli and renal tubules (arrows); (c) diabetic rats received low dose of hibiscus extract $(100 \mathrm{mg} / \mathrm{kg})$ showing marked increase in collagen fibers deposition around renal glomeruli and renal tubules (arrows); (d) diabetic rats received moderate dose of hibiscus extract $(200 \mathrm{mg} / \mathrm{kg}$ ) showing marked increase in collagen fibers deposition around renal glomeruli and renal tubules (arrows); (e) diabetic rats received high dose of hibiscus extract (400 mg/kg) showing moderate increase in collagen fibers deposition around renal glomeruli and renal tubules (arrows); (f) diabetic rats received lisinopril $(5 \mathrm{mg} / \mathrm{kg})$ showing few collagen fibers around renal glomeruli and renal tubules (arrows); (g) diabetic rats received lisinopril ( $2.5 \mathrm{mg} / \mathrm{kg}$ ) plus hibiscus extract ( $100 \mathrm{mg} / \mathrm{kg}$ ) showing few collagen fibers around renal glomeruli and renal tubules (arrows).

In the present study, STZ-treated rats showed reduced $\mathrm{BW}$ and alterations in glycemic parameters including hyperglycemia and reduction of serum insulin level. Our results are similar to previous studies described in the literature (Mohamed et al., 2013).
In the current study, manifestations of DN were evident after 8 weeks of STZ administration. It has been demonstrated that albuminuria associated with DN is attributed to glomerular capillaries dysfunctions (Wolf and Ziyadeh, 2007). Further, it has been described that glomerular changes are manifested as hypertrophy and proliferation of mesangial cells, amassing of extracellular 
matrix $(\mathrm{ECM})$ proteins such as collagen and fibronectin, and thickening of the glomerular basement membrane (Mason and Wahab, 2003). Our results revealed that kidney tissue of STZ-treated rats had increased level of TGF- $\beta 1$. The latter is considered as an important growth factor that enhances the expression of ECM proteins (Jakus and Rietbrock, 2004). In this regard, our results are in accordance with the study of ElMahdy et al. (2016).

The activation of TGF- $\beta 1$ is suggested to involve interplay of different mediators including AGEs, protein kinase $\mathrm{C}$ (PKC), and ROS (Leask and Abraham, 2004). In our model, it was interesting to measure these mediators. Indeed, the results of the present study revealed that $\mathrm{DN}$ was associated with enhanced formation AGEs and increased oxidative stress manifested as elevation of MDA level, reduction of GSH level and reduction in SOD and CAT activities in kidney tissue.

Sustained hyperglycemia is recognized as the main player that initiates the abovementioned deleterious events. Under conditions of chronic hyperglycemia, the formation of AGEs is enhanced through a non-enzymatic interaction between sugars with free amino groups found in structures such as proteins, lipids, and nucleic acids (Schleicher et al., 2001). Through interactions with their receptor known as RAGE, AGEs activates PKC, mitogenactivated protein kinase (MAPK), transcription factors such as $\mathrm{NF}-\kappa \mathrm{B}$, and enhances the formation of ROS leading eventually to increased expression of TGF$\beta 1$ (Forbes et al., 2003; Tan et al., 2007).

Moreover, hyperglycemia is implicated in increasing oxidative stress. Different effects could explain hyperglycemia-induced increase in oxidative stress including excessive ROS production directly via autoxidation of glucose (Sano et al., 1998) or indirectly via AGEs pathway as mentioned previously. In addition, other causes include impairment of the activity of antioxidative enzymes leading to the reduction in their capacity to detoxify ROS and reduction in tissue concentrations of GSH (Haskins et al., 2003). Depletion of GSH might be attributed to the activation of the polyol pathway responsible for the conversion of glucose to sorbitol, which is subsequently oxidized to fructose with a concomitant reduction of GSH (Chung et al., 2003).

Many studies pointed to the important role of chronic inflammation in the development of diabetes and DN (Chow et al., 2004; King, 2008). Recently, Lin et al. (2012) reported that TLR4 pathway can stimulate tubulointerstitial inflammation in DN. The authors suggested also that high glucose concentration upregulated TLR4 expression via the activation of PKC leading to increased levels of inflammatory cytokines such as interleukin (IL)-6 through $\mathrm{NF}-\kappa \mathrm{B}$-dependent manner. $\mathrm{NF}-\kappa \mathrm{B}$ is a transcription factor that promotes the expression of genes involved in inflammation, such as TNF- $\alpha$, IL-1 and chemokines. TNF- $\alpha$ has been demonstrated to enhance the production of ROS and induce changes in glomerular capillary permeability (McCarthy et al., 1998). TNF- $\alpha$ plays also a pivotal role in the development of renal hypertrophy and hyperfunction, which are characteristic features of DN (DiPetrillo and Gesek, 2004). Another study demonstrated that hyperglycemia can activate TLR4 expression and activity in mouse mesangial cells and could contribute to DN (Kaur et al., 2012). Taken together, it was noteworthy to investigate the role of TLR4/NF- $\kappa \mathrm{B} / \mathrm{TNF}-\alpha$ pathway in the development of $\mathrm{DN}$ in our model. We observed that STZ diabetic rats had significantly higher expression of TLR4 and $\mathrm{NF}-\kappa \mathrm{B}$, as well as significant elevation in TNF- $\alpha$ levels compared to normal non- 
diabetic rats. Results are in accordance with the study of Kuhad and Chopra (2009), who demonstrated a similar role of $\mathrm{NF}-\kappa \mathrm{B}$ pathway in DN in STZ diabetic rats.

A causal link has been suggested to exist between TNF- $\alpha$ and nitrosative stress in kidney tissue during settings of DN (Xiao et al., 2009). The authors reported that TNF$\alpha$ can induce iNOS expression which consequently leads to increased production of NO and ultimately results in glomerular lesions. Although NO is not a strong oxidant, however, it can react readily with superoxide anion generated during sustained hyperglycemia forming peroxynitrite, which possesses strong oxidative ability causing structural damage or functional impairment of many important macromolecules (Szabo, 2003). We could detect significant elevation in iNOS expression and NO content in kidney tissue from STZ diabetic rats. In addition, our results match the results of Kuhad and Chopra (2009), who reported a similar increase in NO content in diabetic rats. These results emphasize the multifactorial mechanisms implicated in the pathogenesis of DN and the importance of the crosstalk between these factors in the eventual deleterious alterations in renal function.

The administration of hibiscus extract significantly restored the weight loss and improved disturbances in glycemic parameters induced by STZ. These results are similar to other studies showing the antidiabetic effect of hibiscus extract (Farombi and Ige, 2007; Peng et al., 2011). Further, hibiscus extract was effective in ameliorating DN. In this regard, our results are comparable to the study carried out by Yang et al. (2013) showing similar renoprotective effects of hibiscus in a rat model of type 2 diabetes induced by high fat diet and STZ administration. The hibiscusinduced functional improvement in kidney function was reproduced also as structural improvements in kidney tissue toward the normal histologic picture of the renal corpuscles with moderate increase in collagen fibers deposition around renal glomeruli and renal tubules, particularly with the highest dose level $(400 \mathrm{mg} / \mathrm{kg})$. the reduction of collagen deposition could be explained by the observed reduction in TGF$\beta 1$ expression compared to STZ-treated rats.

The renoprotective effect of hibiscus extract could be attributed, in part, to its antioxidative effect that we observed as significant reduction in MDA level and increase in GSH level, as well as elevation in activities of SOD and CAT in kidney tissue. This reflects the ability of hibiscus extract to scavenge free radicals and to decrease lipid peroxidation which conform to other studies showing similar actions (Olalye and Rocha, 2007; Usoh et al., 2005). In the same way, Mossalam et al. (2011) demonstrated that hibiscus extract $(500$ $\mathrm{mg} / \mathrm{kg}$ ) exerted similar antioxidative effects in kidney tissues from rats exposed to malathion pesticide. On the other hand, hibiscus extract significantly diminished the formation of AGEs, which is comparable to the results reported by Peng et al. (2011).

The anti-inflammatory activity of hibiscus extract seems to play a significant role in its renoprotective effect. The results of the present study revealed that hibiscus extract significantly suppressed the inflammatory TLR4/NF- $\kappa \mathrm{B} / \mathrm{TNF}-\alpha$ pathway. Previous studies pointed to the ability of hibiscus to suppress TNF- $\alpha$ (Fakeye et al., 2008) in mice and to inhibit $\mathrm{NF}-\kappa \mathrm{B}$ activation in human $\mathrm{CaP} \mathrm{LNCaP}$ cells (Chiu et al., 2015). The suppressor effect of hibiscus extract on the expression on NF- $\kappa \mathrm{B}$ might be attributed to the inhibition of c-Jun N-terminal kinase (JNK) and p38 MAPK activation (Kao et al., 2009). However, this is the first study, to our knowledge, reporting the inhibitory effect of hibiscus extract on the expression of TLR4 
and its implication in the protection against DN.

Moreover, hibiscus extract significantly diminished nitrosative stress in the form of decreased expression of iNOS and NO level of the kidney tissue that might be brought about by increased level of TNF- $\alpha$. iNOS is induced during inflammatory conditions thus it can be used to indicate the level of inflammation. Therefore, the ability of hibiscus extract to suppress iNOS expression further explains its antiinflammatory activity. Our results are in harmony with the study of Kao et al. (2009), who demonstrated a similar effect of polyphenols extracted from hibiscus in a rat model of lipopolysaccharide-induced hepatic inflammation.

The results of the present study clearly showed that the renoprotective effects of hibiscus extract were dose-dependent. The highest dose of hibiscus H400 significantly ameliorated the alterations induced by STZ administration better than $\mathrm{H} 200$ or $\mathrm{H} 100$. We compared also the effects of hibiscus to the reference lisinopril, an ACEI. This choice is based on the wide clinical utilization of ACEIs in managing nephropathy in patients with type 1 diabetes (Lewis et al., 1993), type 2 diabetes (Amann et al., 2003), or nondiabetic renal disease (Jafar et al., 2001). Interestingly, the renoprotective effects of $\mathrm{H} 400$ were comparable to the effects of lisinopril (5 $\mathrm{mg} / \mathrm{kg}$ ). This implies the potential of hibiscus as a possible alternative to ACEIs in delaying the progression of DN, which would be highly appraised in situations of ACEIs intolerance due to side effects or contraindications. The administration of ACEIs might be associated with some side effects including the development of dry cough that might be sometimes severe enough to the degree that necessitates drug cessation (Malini et al., 1997) or angioedema (Molinaro et al., 2002). In
ISSN (on-line) 2356_9786

addition, ACEIs have been reported to be teratogenic (Sorensen et al., 1998). Although angiotensin II receptor blockers (ARBs) are considered as suitable alternatives to ACEIs in patients developing cough (Grossman et al., 2000) or angioedema (Cicardi et al., 2004), however, they are similarly teratogenic (Nadeem et $a l ., 2015)$. Some animal studies on the safety of hibiscus extract consumption during pregnancy revealed an increase in postnatal weight gain, delay in the onset of puberty and increase in the body mass index at onset of puberty in the female descendants (Iyare and Nwagha, 2009). However, whether these effects would be anticipated in humans is yet to be determined.

Another interesting finding in the present study was the augmentation of the renoprotective effect of the half dose of lisinopril $(2.5 \mathrm{mg} / \mathrm{kg})$ when combined with the lowest dose of hibiscus extract (H100). This combination resulted in significant improvement compared to the full-dose of lisinopril $(5 \mathrm{mg} / \mathrm{kg})$ or the highest dose of hibiscus extract (H400) alone. Such finding seems promising because it warrants achieving better therapeutic profile without exceeding the optimal therapeutic level, which is a major concern particularly in patients with compromised renal function.

\section{CONCLUSION}

In conclusion, the present study provides an evidence of the therapeutic potential of hibiscus extract for the management of DN. Such protective effects are mediated through its antioxidative and anti-inflammatory effects. Although a few number of studies in literature reported the therapeutic benefit of hibiscus extract against DN, however, the present study introduces a new insight into the role of TLR4 inhibition in the renoprotective effects of hibiscus extract. Moreover, we report here a direct comparison with lisinopril and 
the effects of its combined administration with hibiscus extract. Considering these effects and the safe use of hibiscus in the preparation of beverages, it could be used as an alternative to the conventional ACEIs or at least as an adjunctive to augment their effects in DN.

\section{CONFLICT OF INTEREST}

The authors declare no conflicts of interest.

\section{ACKNOWLEDGMENTS}

The authors acknowledge Dr. Rehab Hasan, Department of Histology, Faculty of Medicine, Al-Azhar University, Cairo, Egypt, for performing the histopathological examination, and Dr. Mohammed Abd ElKader, Department of HorticultureDecoration Plants, Faculty of Agriculture, Zagazig University, Egypt, for identifying the calyces of Hibiscus sabdariffa.

\section{REFERENCES}

Amann B., Tinzmann R. and Angelkort B. (2003): ACE inhibitors improve diabetic nephropathy through suppression of renal MCP-1. Diabetes Care, 26(8): 2421-2425.

Česonienè L., Daubaras R., Viškelis P. and Šarkinas A. (2012): Determination of the total phenolic and anthocyanin contents and antimicrobial activity of Viburnum opulus fruit juice. Plant Foods Hum Nutr, 67(3): 256-261.

Chiu C.-T., Chen J.-H., Chou F.-P. and Lin H.-H. (2015): Hibiscus sabdariffa leaf extract inhibits human prostate cancer cell invasion via down-regulation of Akt/NF-kB/MMP-9 pathway. Nutrients, 7(7): 5065-5087.

Chow F., Ozols E., Nikolic-Paterson D. J., Atkins R. C. and Tesch G. H. (2004): Macrophages in mouse type 2 diabetic nephropathy: correlation with diabetic state and progressive renal injury. Kidney Int, 65(1): 116-128.

Chung S. S., Ho E. C., Lam K. S. and Chung S. K. (2003): Contribution of polyol pathway to diabetes-induced oxidative stress. J Am Soc Nephrol, 14(8 Suppl 3): S233-236.

Cicardi M., Zingale L. C., Bergamaschini L. and Agostoni A. (2004): Angioedema associated with angiotensin-converting enzyme inhibitor use: outcome after switching to a different treatment. Arch Intern Med, 164(8): 910-913.

DiPetrillo K. and Gesek F. A. (2004): Pentoxifylline ameliorates renal tumor necrosis factor expression, sodium retention, and renal hypertrophy in diabetic rats. Am J Nephrol, 24(3): 352359.

Drury R. and Wallington E. (1980): General staining procedures. Carleton's histological techniques: 125-150.

El-Mahdy N. A., El-Sayad M. E.-S. and ElKadem A. H. (2016): Combination of telmisartan with sildenafil ameliorate progression of diabetic nephropathy in streptozotocin-induced diabetic model. Biomed Pharmacother, 81: 136-144.

Fakeye T. (2008): Toxicity and immunomodulatory activity of fractions of Hibiscus sabdariffa Linn (family Malvaceae) in animal models. Afr $\mathrm{J}$ Tradit Complement Altern Med, 5(4): 394-398.

Fakeye T. O., Pal A., Bawankule D. U. and Khanuja S. P. (2008): Immunomodulatory effect of extracts of Hibiscus sabdariffa L. (Family Malvaceae) in a mouse model. Phytother Res, 22(5): 664-668.

Farombi E. O. and Ige O. O. (2007): Hypolipidemic and antioxidant effects of ethanolic extract from dried calyx of Hibiscus sabdariffa in alloxan-induced diabetic rats. Fundam Clin Pharmacol, 21(6): 601-609. 
Forbes J. M., Cooper M. E., Oldfield M. D. and Thomas M. C. (2003): Role of advanced glycation end products in diabetic nephropathy. J Am Soc Nephrol, 14(8 Suppl 3): S254-258.

Grossman E., Messerli F. H. and Neutel J. M. (2000): Angiotensin II receptor blockers: equal or preferred substitutes for ACE inhibitors? Arch Intern Med, 160(13): 1905-1911.

Haskins K., Bradley B., Powers K., Fadok V., Flores S., Ling X., Pugazhenthi S., Reusch J. and Kench J. (2003): Oxidative stress in type 1 diabetes. Ann N Y Acad Sci, 1005: 43-54.

Herrera-Arellano A., Flores-Romero S., Chavez-Soto M. A. and Tortoriello J. (2004): Effectiveness and tolerability of a standardized extract from Hibiscus sabdariffa in patients with mild to moderate hypertension: a controlled and randomized clinical trial. Phytomedicine, 11(5): 375-382.

Iyare E. and Nwagha U. (2009): Delayed puberty onset in rats that consumed aqueous extract of Hibiscus sabdariffa during the juvenile-pubertal period. Pak J Biol Sci, 12(23): 1505.

Jafar T. H., Schmid C. H., Landa M., Giatras I., Toto R., Remuzzi G., Maschio G., Brenner B. M., Kamper A., Zucchelli P., Becker G., Himmelmann A., Bannister K., Landais P., Shahinfar S., de Jong P. E., de Zeeuw D., Lau J. and Levey A. S. (2001): Angiotensinconverting enzyme inhibitors and progression of nondiabetic renal disease. A meta-analysis of patient-level data. Ann Intern Med, 135(2): 73-87.

Jakus V. and Rietbrock N. (2004): Advanced glycation end-products and the progress of diabetic vascular complications. Physiol Res, 53(2): 131142.

Kabour A., Henegar J. R., Devineni V. R. and Janicki J. S. (1995): Prevention of angiotensin II induced myocyte necrosis and coronary vascular damage by lisinopril and losartan in the rat. Cardiovasc Res, 29(4): 543-548.

Kanwar Y. S., Wada J., Sun L., Xie P., Wallner E. I., Chen S., Chugh S. and Danesh F. R. (2008): Diabetic nephropathy: mechanisms of renal disease progression. Exp Biol Med (Maywood), 233(1): 4-11.

Kao E. S., Hsu J. D., Wang C. J., Yang S. H., Cheng S. Y. and Lee H. J. (2009): Polyphenols extracted from Hibiscus sabdariffa L. inhibited lipopolysaccharide-induced inflammation by improving antioxidative conditions and regulating cyclooxygenase-2 expression. Biosci Biotechnol Biochem, 73(2): 385-390.

Kaur H., Chien A. and Jialal I. (2012): Hyperglycemia induces Toll like receptor 4 expression and activity in mouse mesangial cells: relevance to diabetic nephropathy. Am J Physiol Renal Physiol, 303(8): F1145-1150.

Kiernan J. A. (1999): Histological and histochemical methods: theory and practice. Shock, 12(6): 479.

King G. L. (2008): The role of inflammatory cytokines in diabetes and its complications. J Periodontol, 79(8 Suppl): 1527-1534.

Kuhad A. and Chopra K. (2009): Attenuation of diabetic nephropathy by tocotrienol: involvement of $\mathrm{NFkB}$ signaling pathway. Life Sci, 84(9-10): 296-301.

Kumar S., Kumar V. and Prakash O. (2010): Antidiabetic and hypolipidemic activities of Hibiscus tiliaceus (L.) flowers extract in streptozotocin induced diabetic rats. Pharmacologyonline, 2: 1037-1044.

Kuno A., Yamada T., Masuda K., Ogawa K., Sogawa M., Nakamura S., Nakazawa T., Ohara H., Nomura T. and 
Joh T. (2003): Angiotensin-converting enzyme inhibitor attenuates pancreatic inflammation and fibrosis in male Wistar Bonn/Kobori rats. Gastroenterology, 124(4): 1010-1019.

Leask A. and Abraham D. J. (2004): TGFbeta signaling and the fibrotic response. FASEB J, 18(7): 816-827.

Lewis E. J., Hunsicker L. G., Bain R. P. and Rohde R. D. (1993): The effect of angiotensin-converting-enzyme inhibition on diabetic nephropathy. The Collaborative Study Group. N Engl J Med, 329(20): 1456-1462.

Lin M., Yiu W. H., Wu H. J., Chan L. Y., Leung J. C., Au W. S., Chan K. W., Lai K. N. and Tang S. C. (2012): Toll-like receptor 4 promotes tubular inflammation in diabetic nephropathy. $\mathrm{J}$ Am Soc Nephrol, 23(1): 86-102.

Malini P. L., Strocchi E., Zanardi M., Milani M. and Ambrosioni E. (1997): Thromboxane antagonism and cough induced by angiotensin-convertingenzyme inhibitor. Lancet, 350(9070): 15-18.

Mason R. M. and Wahab N. A. (2003): Extracellular matrix metabolism in diabetic nephropathy. J Am Soc Nephrol, 14(5): 1358-1373.

McCarthy E. T., Sharma R., Sharma M., Li J. Z., Ge X. L., Dileepan K. N. and Savin V. J. (1998): TNF-alpha increases albumin permeability of isolated rat glomeruli through the generation of superoxide. J Am Soc Nephrol, 9(3): 433-438.

Mohamed J., Shing S. W., Idris M. H., Budin S. B. and Zainalabidin S. (2013): The protective effect of aqueous extracts of roselle (Hibiscus sabdariffa L. UKMR-2) against red blood cell membrane oxidative stress in rats with streptozotocin-induced diabetes. Clinics (Sao Paulo), 68(10): 1358-1363.
Molinaro G., Cugno M., Perez M., Lepage Y., Gervais N., Agostoni A. and Adam A. (2002): Angiotensin-converting enzyme inhibitor-associated angioedema is characterized by a slower degradation of des-arginine(9)bradykinin. J Pharmacol Exp Ther, 303(1): 232-237.

Mossalam H. H., Abd-El Aty O. A., Morgan E. N., Youssaf S. and Mackawy A. M. H. (2011): Biochemical and ultra structure studies of the antioxidant effect of aqueous extract of hibiscus sabdariffa on the nephrotoxicity induced by organophosphorous pesticide (malathion) on the adult albino rats. Journal of American Science, 7(12): 561-572.

Nadeem S., Hashmat S., Defreitas M. J., Westreich K. D., Shatat I. F., Selewski D. T., Onder A. M., Chiang M., Weaver D. J., Jr., Steinke J., Barcia J., Hernandez J., Hidalgo G., Ingraham S. E., Abitbol C. L., Pan C. and Greenbaum L. A. (2015): Renin Angiotensin System Blocker Fetopathy: A Midwest Pediatric Nephrology Consortium Report. J Pediatr, 167(4): 881-885.

Ng D., Tai B., Koh D., Tan K. and Chia K. (2005): Angiotensin-I converting enzyme insertion/deletion polymorphism and its association with diabetic nephropathy: a meta-analysis of studies reported between 1994 and 2004 and comprising 14,727 subjects. Diabetologia, 48(5): 1008-1016.

Olalye M. T. and Rocha J. B. (2007): Commonly used tropical medicinal plants exhibit distinct in vitro antioxidant activities against hepatotoxins in rat liver. Exp Toxicol Pathol, 58(6): 433-438.

Onyenekwe P. C., Ajani E. O., Ameh D. A. and Gamaniel K. S. (1999): Antihypertensive effect of roselle 
(Hibiscus sabdariffa) calyx infusion in spontaneously hypertensive rats and a comparison of its toxicity with that in Wistar rats. Cell Biochem Funct, 17(3): 199-206.

Packham D. K., Alves T. P., Dwyer J. P., Atkins R., de Zeeuw D., Cooper M., Shahinfar S., Lewis J. B. and Lambers Heerspink H. J. (2012): Relative incidence of ESRD versus cardiovascular mortality in proteinuric type 2 diabetes and nephropathy: results from the DIAMETRIC (Diabetes Mellitus Treatment for Renal Insufficiency Consortium) database. Am J Kidney Dis, 59(1): 75-83.

Parving H. H. (2001): Diabetic nephropathy: prevention and treatment. Kidney Int, 60(5): 2041-2055.

Peng C. H., Chyau C. C., Chan K. C., Chan T. H., Wang C. J. and Huang C. N. (2011): Hibiscus sabdariffa polyphenolic extract inhibits hyperglycemia, hyperlipidemia, and glycation-oxidative stress while improving insulin resistance. J Agric Food Chem, 59(18): 9901-9909.

Rodriguez-Medina I. C., Beltran-Debon R., Molina V. M., Alonso-Villaverde C., Joven J., Menendez J. A., SeguraCarretero A. and Fernandez-Gutierrez A. (2009): Direct characterization of aqueous extract of Hibiscus sabdariffa using HPLC with diode array detection coupled to ESI and ion trap MS. J Sep Sci, 32(20): 3441-3448.

Sano T., Umeda F., Hashimoto T., Nawata H. and Utsumi H. (1998): Oxidative stress measurement by in vivo electron spin resonance spectroscopy in rats with streptozotocin-induced diabetes. Diabetologia, 41(11): 1355-1360.

Schleicher E. D., Bierhaus A., Haring H. U., Nawroth P. P. and Lehmann R. (2001): Chemistry and pathobiology of advanced glycation end products. Contrib Nephrol, (131): 1-9.

Siriwoharn T., Wrolstad R. E., Finn C. E. and Pereira C. B. (2004): Influence of cultivar, maturity, and sampling on blackberry (Rubus L. Hybrids) anthocyanins, polyphenolics, and antioxidant properties. J Agric Food Chem, 52(26): 8021-8030.

Sorensen A. M., Christensen S., Jonassen T. E., Andersen D. and Petersen J. S. (1998): [Teratogenic effects of ACEinhibitors and angiotensin II receptor antagonists]. Ugeskr Laeger, 160(10): 1460-1464.

Sun Y. M., Su Y., Li J. and Wang L. F. (2013): Recent advances in understanding the biochemical and molecular mechanism of diabetic nephropathy. Biochem Biophys Res Commun, 433(4): 359-361.

Szabo C. (2003): Multiple pathways of peroxynitrite cytotoxicity. Toxicol Lett, 140-141: 105-112.

Tan A. L., Forbes J. M. and Cooper M. E. (2007): AGE, RAGE, and ROS in diabetic nephropathy. Semin Nephrol, 27(2): 130-143.

Usoh I., Akpan E., Etim E. and Farombi E. (2005): Antioxidant actions of dried flower extracts of Hibiscus sabdariffa L. on sodium arsenite-induced oxidative stress in rats. Pakistan Journal of Nutrition, 4(3): 135-141.

Wang S.-C., Lee S.-F., Wang C.-J., Lee C.H., Lee W.-C. and Lee H.-J. (2011): Aqueous extract from Hibiscus sabdariffa Linnaeus ameliorate diabetic nephropathy via regulating oxidative status and Akt/Bad/14-3-3 $\gamma$ in an experimental animal model. Evid Based Complement Alternat Med, 2011.

Wolf G. and Ziyadeh F. N. (2007): Cellular and molecular mechanisms of proteinuria in diabetic nephropathy. Nephron Physiol, 106(2): p26-31. 
Xiao H., Li Y., Qi J., Wang H. and Liu K. (2009): Peroxynitrite plays a key role in glomerular lesions in diabetic rats. J Nephrol, 22(6): 800-808.

Yang Y.-S., Huang C.-N., Wang C.-J., Lee Y.-J., Chen M.-L. and Peng C.-H. (2013): Polyphenols of Hibiscus sabdariffa improved diabetic nephropathy via regulating the
ISSN (on-line) 2356_9786

pathogenic markers and kidney functions of type 2 diabetic rats. J Funct Foods, 5(2): 810-819.

Zhishen J., Mengcheng T. and Jianming W. (1999): The determination of flavonoid contents in mulberry and their scavenging effects on superoxide radicals. Food Chem, 64(4): 555-559.

\section{خلاصة نبات الهيبيسكس سابداريفا (الكركديه) تُحسن التأثير الوقائي الكُلوي لليسينوبريل ضد اعتلال الكلية السكري المحدث بالستربتوزوتوسين فئني الجين الجرذان}

\section{نهال سمير وهبه، عمرو عبد الرؤف عبد الغني محمود، مني فؤاد محمود، محمد نجيب محمد زكريا}

يعتبر اعتلال الكلية السكري السبب الرئيسي للمرحلة النهائية للفنشل الكلوي. هناك آليات معقدة تتورط في النشوء المرضي لاعتلال الكلية السكرى بما في ذلك تراكم منتجات الجليكاشن النهائية المتقدمة ،الاجهاد التأكسدي، والالتهاب المتوسط بزيادة تعبير مستقبل شبيه التول ؛. يستخدم نبات الهيبيسكس سابداريفا (الكركديه) على نطاق واسع في المنتجات الغذائية كما له تأثير مضاد للتأكسد، مضاد للالتهاب، مضاد للسكري، ومضاد لارتفاع ضغط الدم ـ تهدف هذه الدراسة إلى بحث دور خلاصة الكركديه ضد اعتلال الكلية السكري المحدث بواسطة الستربتوزوتوسين ومقارنه تأثيره بعقار الليسينوبريل وأيضاً تقييم أثرهما

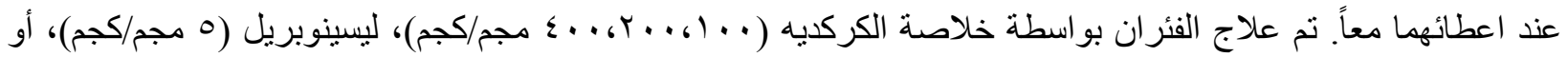

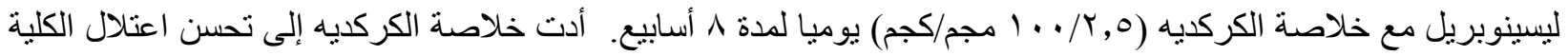
بشكل تابع للجرعة، كما أدت إلى كبح الاجهاد التأكسدي، والآتهاب، وارتفاع معدل التعبير الجيني لمستقبل شبيه التول ؛ المحدث بواسطة الستربتوزوتوسين. وكان تأثيثر خلاصة الكركديه ( . ع مجم/كجم) مشابه لتأثير الليسينوبريل (0 مجم/كجم). وبشكل مثير للانتباه، حَسّن الاعطاء المشترك لليسينوبريل مع خلاصة الكركديه (, (r/... 1 مجم/كجم) مظاهر اعتلال الكلية جو هرياً بشكل أفضل من الليسينوبريل أو خلاصة الكركديه بمفرده. هذه النتائج من المكن أن تدعم استخدام خلاصة الكركديه كبديل لمثبطات الإنزيم المحول للأنجيوتتسين التقليدية أو على الأقل بمثابة مساعد لتعزيز آثار ها في علاج اعتلال الكلية السكري. 